\title{
Improving the Quality of Oocytes of Old and Productive Ages White Rats (Rattus norvegicus) Using Pregnant Mare Serum Gonadotrophin
}

\author{
Sultania A. Suleman', Andriyanto', Aulia Andi Mustika', and Wasmen Manalu' \\ 'Department of Anatomy, Physiology, and Pharmacology, Faculty of Veterinary Medicine, Bogor \\ Agricultural University, Jl Agatis Darmaga, Bogor 16880, Indonesia \\ *Corresponding authors: Wasmen Manalu (wasmenmanalu@ymail.com)
}

\begin{abstract}
This study was conducted to improve the quality of oocytes in old-female rats by using pregnant mare serum gonadotrophin (PMSG). Female rats at productive age were used as a control. The experimental rats were injected with 4 doses of PMSG i.e., 0, 2.5, 5.0, and 10 IU PMSG. After 2 weeks of acclimation to the experimantal condition, the experimental rats were injected with $\mathrm{PGF}_{2 \alpha}$ at a dose of $25 \mu \mathrm{g} / \mathrm{g}$ BW two times with 2 days interval to synchronize estrous cycle. PMSG injections were conducted at the same time with the second PGF 2 injection. After PMSG injection, the experimental rats were divided into two groups rats, i.e., rats without mating for masurement of oocyte qualities and rats mated for measurement of offspring qualities. Therefore, 16 experimental rats from each age group were sacrifized for maeasurement of oocyte qualities. The other 16 experimental rats for each age group were mated for measurement of offspring qualities. Parameters measured were hematological profile, uterine and ovarian weights, the qualities of oocytes, the qualities of the offsspring born by using swimming test and rat maze test. The collected data were analyzed by analysis of variance (ANOVA) and continued with Duncan test with a 95\% confidence level. The data were analyzed using SSPS. The results showed that the improvement in the quality of oocytes in old female rats using the PMSG hormone in this study showed an increase in the quality of oocytes in old and productive age rats. The highest number of oocyte quality was found in rats of productive age (3.25) and significantly different $(P<0.05)$ from the other oocyte qualities. The quality of offspring born to old age and productive age rats injected with PMSG were improved. It was concluded that the improvement of oocyte quality by using PMSG also improves offspring qualities.
\end{abstract}

Key words: oocyte quality, offspring quality, PMSG hormone, old age, productive age

Copyright @ $2019 \mathrm{JRVI}$. All rights reserved.

\section{Introduction}

Reproduction is a biological process to produce new individuals or offspring. Reproduction is the basic method to produce a next generation. However, the qualities of the new generation or individuals to survive in the nature (fitness, intelligence, and immunity) is determined by the qualities of the oocytes and uterine environment during prenatal growth. Therefore, a good quality of offspring can be produced by improving the quality of oocytes and the uterine environment during pregnancy. Oocytes themselves are important cells in various aspects of female fertility, including in the development of ovarian follicles and early embryogenesis (Moussa et al., 2015).10 | P a g e

Oocytes are cells in the ovary that experience meiosis to form the ovum. The quality of oocytes influences the survival of the embryo, formation and maintenance of pregnancy, fetal 
development, and even the health of the individual during adult life (Krisher, 2004). In a normal condition, oocytes in the ovary with the total number of thousand follicles, are not all ovulated. However, based on previous studies, using the PMSG hormone (pregnant mare serum gonadotrophin) can improve and optimize the oocyte quality and prenatal growth of embryos and fetuses during pregnancy by improving the uterine environment.

Research using the PMSG hormone has been carried out in several types of female animals such as pigs, sheep, and several other female animals. The PMSC hormone is a hormone that can help to repair follicles in the productive period of a female animal by injecting it before mating. The use of PMSC to increase the number of follicles and corpus luteum has been shown to increase the secretion of pregnant hormones such as estrogen and progesterone, improve uterine growth, embryo and fetal growth and development, birth weight and weaning weights, growth and development of mammary glands, and milk production in sheep (Manalu and Sumaryadi, 1998; Manalu et al., 1999; Manalu et al., 2000a; Manalu et al., 2000b), cattle (Sudjatmogo et al., 2001), and goats (Adriani et al., 2004).

PMSC has also been known as a standardized form of treatment in optimizing reproductive performance and managing follicle abundance and results to increase estrogen and progesterone secretion during pregnancy (Andriyanto and Manalu, 2011). The dose of PMSC used is $10 \mathrm{IU}$ intraperitoneally (Hogan et al., 2003).

PMSC hormones have been proven for their abilities to improve the reproductive system, pregnancy hormones, mammary glands, to increase the growth and development of the embryo and fetus to support the optimum organ growth and development to support optimum life functions during post natal life. However, all of the above evidences are in the productive or young age of females animals. In female mammalian animals, the egg cells in the ovary are exist during the embryonic stage of the female individual. Therefore, free radicals and oxidants produced by the metabolic system in the body during the life of female animals could decrease the qualities of egg cells. Therefore, the decrease quality offspring produced by the old age maternal animal was related to the decreased quality of egg cells in the ovary. This experiment was designed to improve the qualities of oocytes in the old age female mammalian animals. Old age rats used in this study were rats that had reached the age of 1 year (12 months). Old male rats can reach a body weight of $500 \mathrm{~g}$, but female mice are rarely more than $350 \mathrm{~g}$ (smith and mangkoewidjojo, 1988). Selection of the age of 12 months based on the maximum age of this strain is 1 to 3 years (36 months). the aging process starts at the age of 30 in humans, and if it is estimated that the maximum age of humans is 90 years. Then the aging process in mice analogous to humans begins at the age of 1 year (12 months), the selection of wistar rattus norvegicus strain in this study was due to its similarity to humans.

\section{Materials and Methods}

\section{Experimental Animal Preparations}

The experimental animals used in this study consisted of two age categories i.e., productive age rats with body weights range of 100-200 $\mathrm{g}$ and old age rats with body weights range of 200$300 \mathrm{~g}$. Before the treatment, the experimental rats were acclimatized for 14 days, and placed in cages made of plastic material size $(33 \times 26 \times 12) \mathrm{cm}$ with sterile wood shavings, while the top of the cage was closed by using woven wire and then placed on a special rack of mice in a $20^{\circ} \mathrm{C}$ room temperature. Wood shavings of the cage were replaced every 3 days. Feed given to the experimental rats was feed in the form of pellets containing nutritional composition in accordance with the standard requirements of mice, which consisted of $13 \%$ water, $19-21 \%$ 
protein, $5 \%$ fat, $7 \%$ ash, $0.9 \%$ calcium, and $0.6 \%$ phosphorus. Feeds were given in the morning and in the evening, while drinking water was available ad libitum.

Injection of $P G F_{2 \alpha}$ and PMSG Hormones

The experimental rats used in this study were 64 individuals, consisting of 32 rats at the productive age and 32 rats at the old age. Before injection of $\mathrm{PGF}_{2 \alpha}$, the experimental rats were weighed first to determine the dose of $25 \mu \mathrm{g} / \mathrm{g}$ BB (Rahmandi et al., 2013) in 2x subcutaneously with an interval of 2 days. Injection of $\mathrm{PGF}_{2 \alpha}$ (Lutraprost ${ }^{\circledR} 250$, Agrivet, USA) two times with 2 days interval was designed to synchronize the phase of estrus cycle of the experimental rats. The first injection of $\mathrm{PGF}_{2 \alpha}$ was directed to homogenize the conditions of all experimental animals in the luteal phase which were expected to have an effective response to the second injection. $\mathrm{PGF}_{2 \alpha}$ works to lyse the corpus luteum in the ovary and is followed by the estrous cyclle (Hafez et al., 2000).

\section{Mating Preparation and Surgery}

After the injection of experimental rats with PMSC, then 32 out of a total of 64 experimental rats (consisted of 16 productive age rats and 16 old age rats) were mated with male rats by mixing male and female rats for 3 days. The remaining 32 experimental rats were sacrificed and the ovary and uterus were isolated as well as blood samples were collected for evaluation.

\section{Hematological Profile}

Blood samples of the experimental rats were taken from the caudal vein using spuid no. $20 \mathrm{G}$. Blood samples were taken on day 0 (before mating) and on days 9 and 18 post-mating. Blood samples with anticoagulant tubes were taken to measure the number of neutrophils, lymphocytes, monocytes, basophils, and eosinophils.

\section{Uterus Weight and Ovarian Weight}

Uterine and ovarian were obtained by a surgical procedure. The uterus and ovaries were then cleaned using a Phosphate Buffer Saline (PBS) solution that was provided in a petri dish. Then, the uterine and ovarian samples were inserted into the organ tube containing the PBS solution. The weights of the uterus and ovaries were determined by weighing using an analytical balance.

\section{Analysis of Oocytes Qualities}

Oocyte samples were obtained from ovaries of the experimental rats that had not been mated and were used to analyze oocytes. Oocyte samples were collected by slicing using knifes and scalpel (Engcong and Karja, 2013). The oocytes were grouped based on the percentage value of the quality criteria and then entered into the form of data to the Square Root for a variety analysis (Gaspersz, 1995).

\section{Observations During Postmating Until Delivery}

After mating the experimental female rats by mixing with male rates for 3 days, male rats were removed from the cage. After parturition, the body weights of the maternal experimental rats were weighed and the swimming test were conducted to evaluate the resistance and the fitness of the maternal rats. At the age of 30 days after birth, the offspring experimental rats were weighed, then a swimming test was performed to evaluate the resistance of the offspring experimental rats and rat maze test was conducted to evaluate the intelligence of the offspring rats born. 


\section{The Swimming Test}

The swimming test was conducted in experimental offspring rats at the age of 30 days to evaluate the body resistance and the fitness of the offspring rats. The parameters measured were muscle strength when swimming, swimming agility of the experimental offspring rats, and the ability to swim. The data were obtained from the duration of time for swimming in each experimental offspring rats and used to calculate the mean values.

\section{The Rat Maze Test}

The rat maze test was carried out using the Labyrinth $\mathrm{Y}$ method. Labyrinth $\mathrm{Y}$ was arranged in $\mathrm{Y}$ form, the angle between the feet was equal $\left(120^{\circ}\right)$. The experimental rats were fasted for 18 hours before testing. However, drinking water was still provided. The test was divided into three stages, namely the adaptation stage, the learning stage, and the testing stage. At the adaptation stage, the doors on the labyrinth section were not installed. When the experimental rats entered the labyrinth branch, feed was placed on the right side of the branch. If the rats reacts positively by running towards the food then testing can be proceeded to the next stage. At the learning stage, food was placed on the right branch of the labyrinth before the xperimental rats were released from the cage. In the testing phase, the three doors on each labyrinth branch were closed and food was placed behind the door of the right labyrinth branch. The results of the Labyrinth $\mathrm{Y}$ method test were presented in the narrative form.

\section{Statistical Analysis}

The collected data were analyzed by analysis of variance (ANOVA) test at a significant level of $P<0.05$. If there is a real effect, it will be continued with the Duncan test with a confidence level of $95 \%$ (Steel and Torrie, 1981). Data were processed using the SAS system program.

\section{Results and Discussions}

\section{The weights of the ovary and uterus of Experimental Rats}

The uterus is the female reproductive organ that is generally predominant in mammals and is included in one of the secondary reproductive organs in females (Toelihere, 1985). The uterus has functions for receiving spermatozoa, delivering the spermatozoa to the oviduct, and creating an optimal environment for implantation. The uterus also functions as a place where the normally fertilized ovum is embedded and where the embryo and fetus are growing (Hafez et al., 2000). In this study, the old and productive ages rats were treated with the administration of PMSC hormone with doses of $0 \mathrm{IU}, 2.5 \mathrm{IU}, 5 \mathrm{IU}$, and $10 \mathrm{IU}$. The effect of giving PMSC hormone on ovarian and uterine weights are presented in Table 1.

The ovarian weights and uterine weights of productive and old experimental rats injected with various doses of PMSG are presented in Table 1. The results of the statistical analysis showed that there was no main effect of dose of PMSG injection and age of experimental rats and their interactions on the ovarian weight ( $p>0.05)$. However, old experimental rats injected with 10 IU PMSG had the highest ovarian weight compared to the other doses of PMSG injection followed by productive rats injected with 5 IU PMSG $(p<0.05)$. Control productive experimental rats had significantly higher ovarian weight compared to control old rats without PMSG injection $(\mathrm{P}<0.05)$. 
Table 1 Mean Ovarian Weights and Uterine Weights in Oldage and Productive-age Rats

\begin{tabular}{lll} 
Treatment & $\begin{array}{l}\text { Ovarian weight } \\
\text { Average } \pm S D\end{array}$ & $\begin{array}{l}\text { Uterine weights } \\
\text { Average } \pm S D\end{array}$ \\
\hline KP & $0,46 \pm 0,003^{\mathrm{c}}$ & $0,64 \pm 0,333^{\mathrm{d}}$ \\
PD 1 & $0,46 \pm 0,002^{\mathrm{c}}$ & $1,27 \pm 0,907^{\mathrm{bc}}$ \\
PD 2 & $0,70 \pm 0,001^{\mathrm{ab}}$ & $1,67 \pm 1,011^{\mathrm{b}}$ \\
PD 3 & $0,64 \pm 0,009^{\mathrm{b}}$ & $1,90 \pm 1,66^{\mathrm{a}}$ \\
KT & $0,31 \pm 0,017^{\mathrm{d}}$ & $0,90 \pm 0,301^{\mathrm{cd}}$ \\
TD 1 & $0,51 \pm 0,000^{\mathrm{bc}}$ & $1,20 \pm 0,766^{\mathrm{c}}$ \\
TD 2 & $0,57 \pm 0,004^{\mathrm{bc}}$ & $1,33 \pm 0,699^{\mathrm{bc}}$ \\
TD 3 & $0,80 \pm 0,004^{\mathrm{a}}$ & $1,82 \pm 1,567^{\mathrm{ab}}$ \\
\hline
\end{tabular}

* Presented in averages and SE

ab Superscripts with different letters in the same column show significant differences $(p<0.05)$. KP : Productive rats controls, PD1: 2,5 IU dose of PMSG productive rats, PD2: 5 IU dose of PMSC productive rats, PD3: 10 IU dose of PMSC productive rats, KT :old rat controls, TD1: 2,5 IU dose of PMSC old rats, TD2: 5 IU dose of PMSG old rats, and TD3: 10 IU dose of PMSC old rats.

The dose of PMSC injection and the age of the experimental rats did not show any significant effect on the uterine weight. However, there was an interaction between the age of the experimental rats and the dose of PMSC injection on the weight of the uterus $(p<0.05)$. Productive age and old age experimental rats injected with 10 IU PMSC had similar uterine weights that were significantly higher than the other doses of PMG injections $(p<0.05)$.

\section{White Blood Cells Profiles of Experimental Rats}

White blood cells profile of the experimental rats were measured to evaluate the health conditions and as a baseline reference or control in the study. Ilheidioha et al. (2012) stated that metabolic disorders, diseases, damage to organ structure and function, influence of agents/drugs, and stress can be known from the changes in the blood profile. The white blood cells profiles of experimental rats in this study are presented in Table 2. The data in Table 2 showed that on days 0,9 , and day 18 , there were significant effects of PMSC injection on monocytes $(p<0.05)$. The same results were also found in lymphocytes and neutrophills. However, the dose of PMSG injection did not significantly affect eosinophils and basophils.

Based on the results of the analysis shown in Table 2, eosinophils showed different levels on days 0,9 , and 18 of pregnancy. The results of eosinophils observation in this study showed the healthy condition of the experimental rats during pregnancy. Normal levels of eosinophils in the body are 350 eosinophil cells per microliter of blood, or $0.0 \%-0.6 \%$ in differential count, but this normal range varies between laboratories. Eosinophils control and reduce the incidence of hypersensitivity, and respond to the onset of a disease and allergy (Metha and Hoffbrand, 2014), and detoxification of various substances or poisons caused by parasites or bacteria (Frandson et al., 2009). Monocytes function as phagocytosis, destroying foreign objects and destroying dead tissue by utilizing foreign particles to enhance immunity, such as macrophages in response to antigens (Frandson et al., 2009). The percentage of lymphocytes on days 0, 9, and day 18 of prenancy showed a range of $50-92 \%$, which indicated that lymphocytes were 
very good in these experimental rats. Smith and Mangkoewidjojo (1988) and Guyton and Hall (1997) state that normally the number of lymphocytes is in the range of $24-84 \%$. Neutrophils function to maintain and improve the body's resistance to stress. Neutrophils prevent and fight the attack of bacteria that enter the body.

Table 2 Profiles of Hematological Parameters of Experimental Rats

\begin{tabular}{|c|c|c|c|c|c|c|}
\hline \multirow[b]{2}{*}{$\begin{array}{l}\text { Time } \\
\text { (day) }\end{array}$} & \multirow[b]{2}{*}{ Treatment } & \multicolumn{5}{|c|}{ Parameter } \\
\hline & & $\begin{array}{l}\text { Monocyte } \\
(\%)\end{array}$ & $\begin{array}{l}\text { Lymphocytes } \\
(\%)\end{array}$ & $\begin{array}{l}\text { Neutrophils } \\
\text { (\%) }\end{array}$ & $\begin{array}{l}\text { Eosinophils } \\
(\%)\end{array}$ & $\begin{array}{l}\text { Basophils } \\
(\%)\end{array}$ \\
\hline \multirow{8}{*}{0} & KP & $7.17 \pm 2.3^{\mathrm{ab}}$ & $71.5 \pm 4.37 \mathrm{de}$ & $21.00 \pm 3.52^{\mathrm{a}}$ & $0.33 \pm 0.52^{\mathrm{d}}$ & $0.00 \pm 0.00^{\mathrm{a}}$ \\
\hline & PD 1 & $4.00 \pm 1.26^{\mathrm{cd}}$ & $75.17 \pm 7.08^{b c}$ & $20.67 \pm 5.99^{b}$ & $0.17 \pm 0.41^{d}$ & $0.00 \pm 0.00^{\mathrm{a}}$ \\
\hline & PD 2 & $5.67 \pm 2.50^{\mathrm{b}}$ & $77.00 \pm 6.36^{b}$ & $16.00 \pm 5.02^{c}$ & $1.33 \pm 1.21^{\mathrm{ab}}$ & $0.00 \pm 0.00^{\mathrm{a}}$ \\
\hline & PD 3 & $6.17 \pm 1.33^{\mathrm{bc}}$ & $74.83 \pm 5.60^{\mathrm{cd}}$ & $18.33 \pm 5.20^{b c}$ & $0.67 \pm 0.52^{\mathrm{bc}}$ & $0.00 \pm 0.00^{\mathrm{a}}$ \\
\hline & KT & $6.17 \pm 1.17^{b c}$ & $72.33 \pm 8.82^{c}$ & $21.00 \pm 7.87^{\mathrm{ab}}$ & $0.5 \pm 0.55^{b c}$ & $0.00 \pm 0.00^{\mathrm{a}}$ \\
\hline & TD 1 & $6.00 \pm 1.79 \mathrm{bc}$ & $77.33 \pm 5.68^{b}$ & $16.50 \pm 4.46^{c}$ & $0.17 \pm 0.41^{d}$ & $0.00 \pm 0.00^{\mathrm{a}}$ \\
\hline & TD 2 & $4.17 \pm 2.04^{c}$ & $79.67 \pm 3.72^{b}$ & $15.50 \pm 3.39 \mathrm{~cd}$ & $1.21^{\mathrm{bc}}$ & $0.00 \pm 0.00^{\mathrm{a}}$ \\
\hline & TD 3 & 5.33 & $77.83 \pm 4.79 \mathrm{bc}$ & 16.67 & 0.17 & $0.00 \pm 0.00^{a}$ \\
\hline \multirow{8}{*}{9} & $\mathrm{KP}$ & 3.67 & $1.73^{\mathrm{ab}}$ & 8.33 & $.00^{e}$ & $0.00^{\mathrm{a}}$ \\
\hline & PD 1 & $3.33 \pm 0.58^{\mathrm{e}}$ & $91.00 \pm 1.73^{a}$ & $5.67 \pm 1.15^{e}$ & $0.00 \pm 0.00^{e}$ & $0.00 \pm 0.00^{\mathrm{a}}$ \\
\hline & PD 2 & $4.67 \pm 2.52^{\mathrm{bc}}$ & $82.00 \pm 2.00^{\mathrm{bc}}$ & $13.33 \pm 0.58^{d}$ & $0.00 \pm 0.00^{e}$ & $0.00 \pm 0.00^{\mathrm{a}}$ \\
\hline & PD 3 & $6.33 \pm 1.53^{b c}$ & $71.00 \pm 2.00^{d}$ & $23.00 \pm 1.00^{b c}$ & $0.00 \pm 0.00^{e}$ & $0.00 \pm 0.00^{a}$ \\
\hline & KT & $2.33 \pm 1.53^{e}$ & $86.67 \pm 6.11^{\mathrm{a}}$ & $11.00 \pm 4.58^{d}$ & $0.00 \pm 0.00^{e}$ & $0.00 \pm 0.00^{\mathrm{a}}$ \\
\hline & TD 1 & $6.00 \pm 2.00^{\mathrm{b}}$ & $78.67 \pm 2.52^{c}$ & $15.33 \pm 0.58^{\mathrm{d}}$ & $0.00 \pm 0.00^{e}$ & $0.00 \pm 0.00^{\mathrm{a}}$ \\
\hline & TD 2 & 8.3 & 69. & $1.0^{\mathrm{bc}}$ & $00^{e}$ & $0.00 \pm 0.00^{\mathrm{a}}$ \\
\hline & TD 3 & 4.3 & 77. & 17.3 & 0.6 & $\pm 0.00^{a}$ \\
\hline \multirow{8}{*}{18} & KP & $5.00 \pm$ & $76.00 \pm 1.00^{d}$ & 18.33 & $58^{\mathrm{bc}}$ & $0.00 \pm 0.00^{a}$ \\
\hline & PD 1 & $5.00 \pm 1.00^{c}$ & $76.00 \pm 1.00^{d}$ & $18.33 \pm 1.15^{\text {sd }}$ & $0.67 \pm 0.58^{\mathrm{bc}}$ & $0.00 \pm 0.00^{\mathrm{a}}$ \\
\hline & PD 2 & $5.33 \pm 2.89^{b}$ & $80.67 \pm 6.66^{b}$ & $13.67 \pm 3.51^{\mathrm{de}}$ & $0.33 \pm 0.58^{\mathrm{cd}}$ & $0.00 \pm 0.00^{\mathrm{a}}$ \\
\hline & PD 3 & $6.00 \pm 2.65^{b}$ & $71.67 \pm 4.73^{d}$ & $21.00 \pm 6.08^{b}$ & $1.33 \pm 1.53^{\mathrm{a}}$ & $0.00 \pm 0.00^{\mathrm{a}}$ \\
\hline & KT & $4.00 \pm 1.00^{c d}$ & $69.33 \pm 4.04^{\mathrm{d}}$ & $26.00 \pm 3.00^{\mathrm{ab}}$ & $0.67 \pm 0.58^{\mathrm{bc}}$ & $0.00 \pm 0.00^{\mathrm{a}}$ \\
\hline & TD 1 & $5.33 \pm 3.06^{\mathrm{b}}$ & $82.33 \pm 2.08^{b}$ & $12.00 \pm 4.36^{\mathrm{de}}$ & $0.33 \pm 0.58^{\mathrm{cd}}$ & $0.00 \pm 0.00^{\mathrm{a}}$ \\
\hline & TD 2 & $7.33 \pm 1.53^{b}$ & $66.67 \pm 8.62^{\mathrm{de}}$ & $25.33 \pm 6.66^{\mathrm{a}}$ & $0.67 \pm 0.58^{\mathrm{bc}}$ & $0.00 \pm 0.00^{\mathrm{a}}$ \\
\hline & TD 3 & $4.67 \pm 2.08^{c}$ & $78.33 \pm 1.15^{d}$ & $16.67 \pm 0.58^{\mathrm{de}}$ & $0.33 \pm 0.58^{\mathrm{cd}}$ & $0.00 \pm 0.00^{a}$ \\
\hline
\end{tabular}

* Presented in averages and SE

ab Superscripts with different letters in the same column show significant differences. KP : Productive rats controls, PD1: 2,5 IU dose of PMSC productive rats, PD2: 5 IU dose of PMSC productive rats, PD3: 10 IU dose of PMSC productive rats, KT :old rat controls, TD1: 2,5 IU dose of PMSC old rats, TD2: 5 IU dose of PMSG old rats, and TD3: 10 IU dose of PMSG old rats.

\section{Effect of PMSG administration on the quality of oocytes in productive and old age rats}

Oocytes are central to regulating various aspects of female fertility, including the development of ovarian follicles and early embryogenesis (Moussa et al., 2015). The quality of oocytes in the reproductive process is indeed very important in producing offspring having better performances in terms of immunity, intelligence, fitness, and reducing mortality. The quality of oocytes influences the survival of the early embryo, the formation and maintenance of pregnancy, fetal development, and even adult disease (Krisher 2004). Based on the results of observations in this study, the number of oocytes with grade $A, B, C$, and D qualities are presented in Table 3.

The results of data analysis showed that there was a significant effect of PMSC injection on the oocytes qualities of experimental rats. As was seen in Table 2, the number of good quality of oocyte in productive age experimental rats was higher compared to the old age group $(p<0.05)$. In addition, the number of lower quality oocytes were higher in old age experimental rats compared to productive age experimental rats $(p<0.05)$. For old age group 
without PMSG injection (KT) the number of low quality oocytes were higher compared with productive age group rats without PMSG injection (KP). Improvement of oocytes qualities was also seen in productive age rats injected with 2.5 IU PMSC (KP1) when compared with the old age rats injected with PMSG at a dose of 2.5 IU (TD1), eventhough the quality of oocytes was still much better in productive age rats than in old rats. This result is related to the fact that indirectly PMSG is the same hormone as the hormone that stimulates the development of oocytes, namely gonadotropin. In the process of oocyte development, the hormone needed is Gonadotropin Hormone (GTH). GTH which plays a role in gonadal development activities are follicle stimulating hormone (FSH) and Luteinizing hormone ( $\mathrm{LH})$, each of which has two glycoprotein subunits, namely FSH responsible for the development of oocytes (vitelogenesis) and LH as triggers the oocyte maturity (Nagahama, 1987; Nagahama et al., 1994). However, the reverse results were found in productive age rats injected with 5 IU PMSG (PD2 treatment) where the quality of oocytes was smaller compared to the old age rat injected with PMSC at a dose of 5 IU (TD2). In both treatments, there were significant differences in oocyte quality. Oocyte quality improvement is influenced by the PMSG hormone, because PMSC has a direct influence on oocyte maturation by stimulating the development of oocyte nuclei so that the number of oocytes that stop development is only in a small number. With the development of more oocytes, the number of $\mathrm{CL}$ that will be formed after ovulation will be higher. For productive age rats (PD3) and old age rats (TD3) injected with 10 IU PMSC did not show significant results.

Table 3 Quality of Oocyte in Productive Age and Old Age Rats

\begin{tabular}{lcccc}
\hline \multirow{2}{*}{ Treatment } & \multicolumn{4}{c}{ The number of oocytes in each grade } \\
Mean $\pm S E$
\end{tabular}

* Presented in averages and SE

ab Superscripts with different letters in the same column show significant differences. A: Oocytes have five layers or more cumulus cells with a homogeneous and black cytoplasm. B: oocytes that have less than five layers of cumulus cells with a homogeneous and black cytoplasm. C: oocytes which are still seen in a few layers of cumulus cells, visible zone of pellucida and non-homogeneous cytoplasm. D: oocytes that have transparent cytoplasm, zones of pellucida are seen or even none at all and the cumulus cell layer is almost gone or completely lost.

Oocytes were grouped in Quality A if the oocytes have five or more layers of cumulus cells with a homogeneous and black cytoplasm. Oocytes were grouped in Quality B if the oocytes had less than five layers of cumulus cells with a homogeneous and black cytoplasm. Oocytes were grouped in Quality C if the oocytes showed few layers of cumulus cells, zones of pellucida was observed and cytoplasm that was not homogeneous. Oocytes grouped in Quality D were oocytes having transparent cytoplasm, zone pellucida was seen or even none at all and the cumulus cell layer was almost lost and completely lost (Ikhwan et al., 2016). Quality, or developmental competence, was obtained during folliculogenesis as a growing oocyte, and during the oocyte maturation period (Krisher 2004). The deficit of oocyte competency can cause not only the failure of fertilization but also the lower levels of development after fertilization. Thus, an environment suitable for oocyte growth and maturation, in vivo and in vitro, is very important to ensure the optimal oocyte quality (Moussa et al., 2015). 
Experimental rats that received treatment were 32 individuals consisting of 16 productive-age females and 16 old-age females. The number of rats born was 46 from the experimental rats in productive age and 42 from the experimental rats of old age. Female experimental rats that gave birth were only 17 rats out of a total of 32 experimental rats, i.e., 9 maternal rats of productive age and 8 maternal rats of old age. The number of rats surviving from birth to weaning age ( 30 days) can be seen in Table 4).

Table 4 Birth Weight and Preweaning weights

\begin{tabular}{llllll} 
Treatment & $\begin{array}{l}\text { Number } \\
\text { of } \\
\text { maternal } \\
\text { rats }\end{array}$ & $\begin{array}{l}\text { Number } \\
\text { of } \\
\text { offspring }\end{array}$ & $\begin{array}{l}\text { Birth weight } \\
(g)\end{array}$ & $\begin{array}{l}\text { Number } \\
\text { of } \\
\text { Average } \pm \text { SE }\end{array}$ & $\begin{array}{l}\text { Offspring } \\
\text { Weaning weight } \\
(g)\end{array}$ \\
\hline KP & 3 & 17 & $24.35 \pm 5.13^{\mathrm{d}}$ & 7 & $77.65 \pm 75.75^{\mathrm{c}}$ \\
PD 1 & 2 & 10 & $27.95 \pm 3.39^{\mathrm{cd}}$ & 4 & $141 \pm 15.56^{\mathrm{c}}$ \\
PD 2 & 2 & 9 & $32.67 \pm 4.86^{\mathrm{c}}$ & 5 & $182 \pm 35.36^{\mathrm{b}}$ \\
PD 3 & 2 & 10 & $38.79 \pm 0.87^{\mathrm{b}}$ & 6 & $243.5 \pm 20.51^{\mathrm{a}}$ \\
\hline Total & 9 & 46 & $123.76 \pm 14.25^{\mathrm{b}}$ & 22 & $643.65 \pm 147.18^{\mathrm{a}}$ \\
\hline KT & 2 & 12 & $26.93 \pm 0.78^{\mathrm{e}}$ & 5 & $125.5 \pm 0.71^{\mathrm{e}}$ \\
TD 1 & 2 & 11 & $34.2 \pm 3.08^{\mathrm{c}}$ & 4 & $94.5 \pm 44.55^{\mathrm{d}}$ \\
TD 2 & 2 & 10 & $37.50 \pm 0.95^{\mathrm{bc}}$ & 6 & $223.5 \pm 7.78^{\mathrm{ab}}$ \\
TD 3 & 2 & 9 & $36.57 \pm 5.73^{\mathrm{a}}$ & 5 & $190.5 \pm 41.7 \mathrm{ab}$ \\
\hline Total & 8 & 42 & $135.2 \pm 10.54^{\mathrm{a}}$ & 20 & $634 \pm 94.76^{\mathrm{b}}$ \\
\hline
\end{tabular}

* Presented in averages and SE

ab Superscripts with different letters in the same column show significant differences. KP : Productive rats controls, PD1: 2,5 IU dose of PMSC productive rats, PD2: 5 IU dose of PMSC productive rats, PD3: 10 IU dose of PMSC productive rats, KT :old rat controls, TD1: 2,5 IU dose of PMSC old rats, TD2: 5 IU dose of PMSG old rats, and TD3: 10 IU dose of PMSG old rats.

Based on observations in this study, birth weights as seen in Table 5 are very clear showing very different results between old age rats and productive age rats on the different doses of $0 \mathrm{IU}$, $2.5 \mathrm{IU}, 5 \mathrm{IU}$, and $10 \mathrm{IU}$ PMSC. In each treatment as was shown in Table 4, there were differences in increasing the weight of offspring born to old age rats and productive age rats. This proves that giving PMSC hormone before mating greatly affects the birth weight of offspring. These results are similar to the results of previous studies that the use of PMSC to increase the number of follicles and the corpus luteum has been shown to increase the secretion of pregnancy hormones, uterine growth, embryo and fetus, birth weight and weaning weights, growth and development of mammary glands, and production milk in sheep (Manalu and Sumaryadi, 1998; Manalu et al., 1999; Manalu et al., 2000a; Manalu et al., 2000b), cattle (Sudjatmogo et al., 2001), and goats (Adriani et al., 2004). The PMSC hormone can help optimize follicle development and ripen the oocyte nucleus during the process of animal pregnancy. Increased performance of the follicle and followed by the performance of pregnancy hormones, can help increase the child's body weight. This is due to, during pregnancy, PMSC hormones are able to optimize the performance of pregnancy hormones so as to help the development of children become better including the child's body weight. According to Dian (2007), the number of children per mother per birth depends on the age and size of the parent body while the parent nutrition will determine body size or the average birth weight of the child. 


\section{Evaluation of Test Rat Maze and Swimming Test}

After laboratory tests on the quality of oocytes in the first group, 32 rats were mated to the second group and were kept until delivery until the age of the offspring reached 30 days, followed by a swimming test and test rat maze in the rats. The swimming test results were processed in the form of an average and standard deviation in order to see the difference swimming test results between productive rats and old age rats. The results of these tests can be seen in Table 5.

Table 5 Average Results of Time (minutes) during Swimming Test

\begin{tabular}{llll} 
Treatment & $\begin{array}{l}\text { Number of } \\
\text { offspring rats }\end{array}$ & $\begin{array}{l}\text { Time (second) } \\
\text { Average } \pm \text { SE }\end{array}$ & $\begin{array}{l}\text { Body weight }(g) \\
\text { Average } \pm S E\end{array}$ \\
\hline Productive age rats & 3 & $31,54 \pm 0,20^{\mathrm{a}}$ & $132 \pm 90,16^{\mathrm{a}}$ \\
Old age rats & 3 & $31,13 \pm 0,50^{\mathrm{b}}$ & $108,75 \pm 61,93^{\mathrm{c}}$ \\
\hline
\end{tabular}

* Presented in averages and SE

ab Superscripts with different letters in the same column show significant differences

Based on the results of the observations seen in Table 6, it is very clear that there is a significant difference in the ability and the fitness of the offspring rats that are significant between experimental offspring rat born to old age rats and productive age rats. The results explained, even though some offspring rats died before they reached 30 days of age, the body fitness were good enough to survive up to 30 days of age. Conditions in the maternal uterus can affect the health of the child not only during the baby, but also until the age of the adult (Bygren et al., 2014).

Based on the results of observations during the Labyrinth $Y$ test, the results were quite satisfactory which was shown by rats born to the maternal rats of old age as well as from the productive age rats. Experimental rats were able to go through the Labyrinth $Y$ test very actively, even though several times they failed in passing the Labyrinth $Y$ test.

\section{Conclusion}

PMSC can be used to improve the quality of oocytes both in old and young female mammalian animals.

\section{Acknowledgment}

The author would like to thank Study Program of Physiology and Pharmacology Veterinary Medicine of Bogor Agricultural University. The author is also grateful to all the supervisors who have guided the author in this study, and the author would like to thank all the friends involved in this research. The author states there is no conflict of interest with the parties concerned in this research.

\section{References}

Adriani, Sutama, IK., Sudono, A., Sutardi, T., Manalu, W. 2004. Pengaruh superovulasi sebelum perkawinan dan suplementasi seng terhadap produksi susu kambing peternakan etawah. Anim. Prod. 6(2):86-94.

Andriyanto, A., Manalu, W. 2011. Increased goat productivity through the improvement of endogenous secretion of pregnant hormones by using follicle stimulating hormone. Anim. Prod. J. 9(2): 89-93 
Baygren, LO., Petter, T., Cartensen, J., Edvinsson, S., Kaati, G., Pembrey, ME., Sjostrom, M. 2014. Change in paternal grandmothers early food supply influenced cardiovascular mortality of the female grandchildren. Bio. Med. Centr. Genetic. 15:2.

Engcong, DM., Karja, NW. 2013. Kualitas oosit domba dari ovarium setelah penyimpanan pada suhu dan periode waktu yang berbeda. Acta Veterinaria Indonesiana 1(2): 44-49.

Frandson, RD., Wilke, WL., Fails, AD. 2009. Anatomy and Physiology of Farm Animal $7^{\text {tn }}$ ed. lowa State University Press. Wiley-Blackwell. Pp. 12-13..

Gaspersz, V 1995. Teknik Analisis dalam Penelitian Percobaan, Jilid 1. Tarsito. Bandung. Pp 123131, 198-204.

Guyton, AC., Hall, JE. 1997. Fisiologi Kedokteran. EGC:Jakarta. (Diterjemahkan oleh Irawati KA. Tengadi dan A Santoso).

Hafez, ESE., Jainudeen, MR., Rosnina, Y. 2000. Hormones, growth factor and reproduction. In: Hafez ESE, Hafez B. 2000. Reproduction in Farm Animals. $7^{\text {th }}$ Edition. Maryland (US): Lippincott William and Wilkins. Pp. 33-54.

Hogan, B., Costantini, F., Lacy, E. 2003. Manipulating the Mouse Embryo: A Laboratory Manual. $3^{\text {rd }}$ Ed. New York, USA: Cold Spring Harbor Laboratory Press.

Ikhwan, N., Solihati, N., Rasad, S.D., Widyastuti, R. 2016. Perubahan ukuran folikel ovarium dan kualitas oosit pada ovarium domba lokal pasca preservasi dengan waktu yang berbeda. Jurnal IImu Ternak. 16(1): 36-41.

Ilhedioha, Jl., Ugwuja, Jl., Neol-Uneke, OA., Udeani, IJ., Daniel-Igwe, G. 2012. Reference values for the haematology profile of conventional grade outbred Albino mice (Mus musculus) in Nsukka, Eastern Nigeria. Animal Research International 9(2):1601-1612.

Krisher, RL. 2004. The effect of oocyte quality on development. J Anim Sci. 82 (E-Suppl 13): E14-E23.

Manalu, W., Sumaryadi, MY., Sudjatmogo, Satyaningtijas, A. 1999. Mammary gland differential growth during pregnancy in superovulated Javanese thin-tail ewes. Small Rumin. Res. 33(3): 279-284.

Manalu, W., Sumaryadi, MY., Sudjatmogo, Satyaningtijas, A. 2000a. Effect of superovulation prior to mating on milk production perfomance during lactation in ewes. J. Dairy Sci. 83(3): 477-483.

Manalu, W., Sumaryadi, MY., Sudjatmogo, Satyaningtijas, A. 2000b. Effect of superovulation of Javanese thin-tail ewes prior to mating on lamb birth weight ad preweaning growth. Asian-Aus. J. Animal. Sci. 13(3): 292-299.

Manalu, W., Sumaryadi, MY. 1998. Maternal serum progesterone concentration during gestation and mammary gland growth and development at parturition in japanese thintail ewes a carrying single or multiple fetuse. Small Rumin. Res. 27(2): 131 - 136.

Mehta, AB., Hoffbrand, AV. 2008. Haematology at a Glance. Jakarta: Erlangga.

Moussa, M., Shu, J., Zhang, XH., Zeng, F. 2015. Maternal control of oocyte quality in cattle "a review". Anim Reprod Sci. 155:11-27.

Nagahama, Y. 1987. Gonadotropin action on gametogenesis and steroidogenesis in teleost gonads. Zool Sci 4:209-222.

Nagahama, Y. 1994. Endocrine regulation of gametogenesis in fish. Int J. Dev Biol. 38(2):217229.

Rahmandi, R., Siregar, TN., Akmal, M., Armansyah, T., Syahrifuddin, S. 2013. Peningkatan aktifitas luteolitik setelah pemberian ekstrak vesikula seminalis sapi pada tikus putih. $J$. Kedokteran Hewan. 7(1):65-70.

Smith, BJ., Mangkoewidjojo, S. 1988. Pemeliharaan, Pembiakan dan Penggunaan Hewan Percobaan di Daerah Tropis Indonesia. University Press. Jakarta

Steel, RGD., Torrie, JH. 1981. Principles and Procedures of Statistic. London: McGraw-Hill Book Co. Inc. Pub. Ltd. 
Sudjatmogo, Utomo, B., Subiharta, Manalu. W., Ramelan. 2001. Tampilan produksi susu akibat peningkatan pertumbuhan ambing sapi perah Friesian Holstein yang disuntik PMSC pada program perkawinannya. J. Trop. Anim. Dev. 26:8-13.

Toelihere, RM. 1985. Fisiologi Reproduksi Pada Ternak. Bandung (ID): Penerbit Angkasa Bandung. 